\title{
Ontogeny of Myocardial Adrenoceptors II. Alpha Adrenoceptors
}

\author{
ROBIN A. FELDER, ${ }^{(4)}$ PHILIP L. CALCAGNO, GILBERT M. EISNER, AND PEDRO A. JOSE \\ Departments of Pediatrics, Physiology and Biophysics and Medicine, Georgetown University Medical Center, \\ Washington, DC, U.S.A.
}

\begin{abstract}
Summary
The maturation of myocardial alpha adrenoceptors was investigated in dogs. Alpha adrenoceptors were characterized by radioligand binding using $\left[{ }^{3} \mathrm{H}\right]-W B 4101$. In neonatal cardiac membranes, the binding of the ligand was rapid, reversible, of high affinity, saturable and stereoselective. The competition studies with adrenergic agonists and antagonists were indicative of alpha adrenoceptors. In adult dog cardiac membranes, consistent specific binding of the ligand could not be demonstrated. These studies indicate that there is a decrease in alpha adrenergic receptor density of canine cardiac membranes during maturation.
\end{abstract}

\section{Speculation}

Changes in membrane receptor density and affinity may be important mechanisms in the ontogeny of myocardial function.

Previous studies seeking to identify alpha adrenoceptors in myocardial tissue have yielded varying results $(2,9,33,35,37)$. Using the radioligand, dihydroergocryptine, Wei and Sulakhe (35) have demonstrated the presence of alpha adrenoceptors in rat myocardium but not in the dog. They were similarly unable to detect alpha adrenoceptors in the myocardium of either rabbit or guinea pig; however, Karliner et al. (19) using the alpha 1 adrenoceptor antagonist, prazosin, as the ligand, demonstrated the presence of alpha adrenoceptors in the guinea pig myocardium. Recently, Cheng et al. (9) reported that the fetal sheep heart had alpha adrenoceptors, although similar receptors could not be demonstrated in the ewe. In a previous report from this laboratory, age related changes in beta receptor density were demonstrated in the myocardium of the dog (24). Although beta adrenoceptor affinity remained constant during maturation, maximum receptor density increased with age. The present study was undertaken to determine whether alpha adrenoceptors in dog myocardium also show age related changes.

\section{MATERIALS AND METHODS}

Adult mongrel dogs kept on a standard laboratory diet (Purina Chow) and puppies, $1-5$ wk old, were sacrificed by the intravenous administration of sodium pentobarbital. The heart was immediately excised. After removal of the pericardium, it was washed and then placed in cold $\left(4^{\circ} \mathrm{C}\right)$ buffer consisting of $0.25 \mathrm{M}$ sucrose, 5 $\mathrm{mM}$ Tris chloride and $1 \mathrm{mM}$ magnesium chloride adjusted to $\mathrm{pH}$ 7.5. The epicardial fat and great vessels were removed from the heart and minced at $4^{\circ} \mathrm{C}$. Hearts from 3-4 puppies were pooled for each assay. In the adult dog, one heart was used in each experiment. Homogenates were prepared in a dounce homogenizer fitted with ground glass pestle. Partially purified cardiac membranes were prepared according to the method of Alexander et al. (1). The protein recovery ( $\mathrm{mg}$ protein.g wet weight, mean \pm S.E.) was $0.84 \pm 0.10$ in puppies, $1-2$ wk old, $(n=8) ; 0.83 \pm$ 0.31 in puppies, $3-5$ wk old, $(n=3)$; and $0.79 \pm 0.19$ in adult dogs $(n=6)$. There were no differences in protein recovery in these age groups. In order to determine further that this method of membrane preparation gave valid comparisons among age groups studied, adenylate cyclase activity was also measured in crude and partially purified membranes before and after sodium fluoride $\left(10^{-2} \mathrm{M}\right)$ stimulation. Adenylate cyclase activity was measured according to the method of Solomon et al. (3i). The sodiumfluoride-stimulated adenylate cyclase activity in the $30,000 \times g$ fraction was 2.5 times that of the sodium-fluoride-stimulated adenylate cyclase activity in the crude homogenates of all groups studied including the adult. The sodium-fluoride-stimulated adenylate cyclase activity was greatest in the $30,000 \times g$ fraction, with the values of $99.7 \mathrm{pmole} / \mathrm{mg}$ protein $/ \mathrm{min}$ at $1 \mathrm{wk}(n=2), 96.9$ $\mathrm{pmole} / \mathrm{mg}$ protein $/ \mathrm{min}$ at $3-5 \mathrm{wk}(n=2)$ and $204.9 \mathrm{pmole} / \mathrm{mg}$ protein $/ \mathrm{min}$ in adults $(n=2)$. It should also be noted that Bers (4) using more purified membranes showed that the specific activity of pure sarcolemmal membranes were qualitatively similar in neonatal and adult hearts.

Binding assay. Alpha adrenoceptors were assayed using the radioligand $\left[{ }^{3} \mathrm{H}\right]-$ WB4101 $(2,6$ dimethoxyphenoxy-ethyl amino methyl 1,4 benzodioxane) a highly specific alpha 1 adrenoceptor antagonist $(18,32,38)$. Assays were performed in triplicate. The partically purified cardiac membranes were incubated with the radioligand at $23^{\circ} \mathrm{C}$ for $10 \mathrm{~min}$. The incubation buffer consisted of $50 \mathrm{mM}$ Tris- $\mathrm{Cl}, 10 \mathrm{mM} \mathrm{MgCl}, \mathrm{pH}$ 7.5. The bound ligand was separated from the free ligand using the rapid filtration technique of Lefkowitz (21). In each experiment, nonspecific binding was determined by the coincubation of the membranes and the radioligand in the presence of $100 \mu \mathrm{M} \mathrm{L}$-norepinephrine. Total binding was the amount of radioligand bound in the absence of norepinephrine. The specific binding was the difference between total and nonspecific binding. Specific binding was corrected for protein concentration. Maximum receptor occupancy $\left(\mathbf{R}_{0}\right)$ and dissociation constant $\left(\mathbf{K}_{d}\right)$ were calculated from Scatchard plots $(28)$. Protein concentration was measured by the method of Lowry $e t$ al. (22). Since alpha adrenoceptors have been described in rat heart, membranes prepared from this animal was used as reference tissue (37).

The standard for comparing the groups of animals was receptor per mg protein. As mentioned above, the protein recovery in our membranes was similar in all age groups studied. Further justification for this reference standard could be obtained from the report of Cole et al. (10). These authors found that tissue recovery (mg protein per $\mathrm{g}$ of wet tissue weight) remained constant during development.

The values are presented as mean \pm S.E. Statistical significance was ascertained by the Student's $t$ test. A $P$ value of 0.05 or less was accepted as significant.

\section{RESULTS}

In partially purified rat cardiac membranes, the reference tissue, the specific binding of $\left[{ }^{3} \mathrm{H}\right]-\mathrm{WB} 4101$ was approximately $50 \%$. The $\mathrm{K}_{d}$ was $1.126 \pm 0.30 \mathrm{nM}(n=4)$ and the $\mathrm{R}$. was $316 \pm 147 \mathrm{fmole} /$ 
mg protein. Similar results have been reported by Williams and Lefkowitz (37) and by Raisman et al. (26). In partially purified cardiac membranes from adult dogs however, no specific binding of $\left[{ }^{3} \mathrm{H}\right]-$ WB4101 could be consistently demonstrated $(n=4)$. In contrast, $\left[{ }^{3} \mathrm{H}\right]$-WB4101 binding to cardiac plasma membranes from puppies $(n=4)$ was rapid (T $1 / 2=32 \mathrm{sec})$ reaching a steady state within $5 \mathrm{~min}$ and remained at a steady state for at least 30 min. Specific binding was saturable at $40-50 \%$ and remained linear throughout the protein concentration range of $0.2-2.5 \mathrm{mg} /$ $\mathrm{ml}$. Competition studies with agonists (Fig. 1) or antagonists (Fig. 2) were consistent for alpha adrenoceptors. The potency sequence for agonists was epinephrine $>$ norepinephrine $>$ isoproterenol. Stereospecificity was also demonstrated $(-)$-norepinephrine $>$ $(+)$-norepinephrine $>(-)$-isoproterenol $>(+)$-isoproterenol. The potency sequence for antagonists: prazosin $>$ yohimbie $\gg$ propranolol.

The $R_{0}$ and $K_{d}$ values in puppies are shown in Table 1 . In these experiments the concentration of $\left[{ }^{3} \mathrm{H}\right]-$ WB4 101 used was $1-10$ $\mathrm{nM}$. The $\mathrm{K}_{\mathbf{d}}$ was similar in the two groups of puppies studied. The $R$. at 1 wk was $233 \pm 63 \mathrm{fmole} / \mathrm{mg}$ protein. In the $3-5$-wk-old

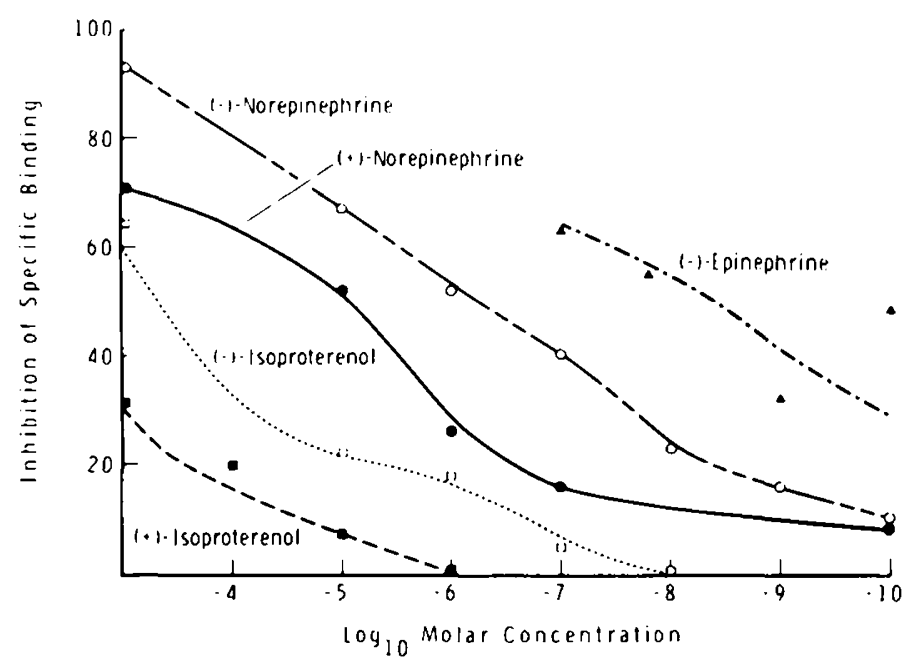

Fig. 1. The effect of varying concentrations of cold adrenergic agonists on the \% inhibition of specific binding of $\left[{ }^{3} \mathrm{H}\right]-$ WB4 101 . Each poin represents the mean of at least four experiments performed in triplicate. The concentration of $\left[{ }^{3} \mathrm{H}\right]-\mathrm{WB} 4101$ used in these experiments ranged from 4-7 nM.

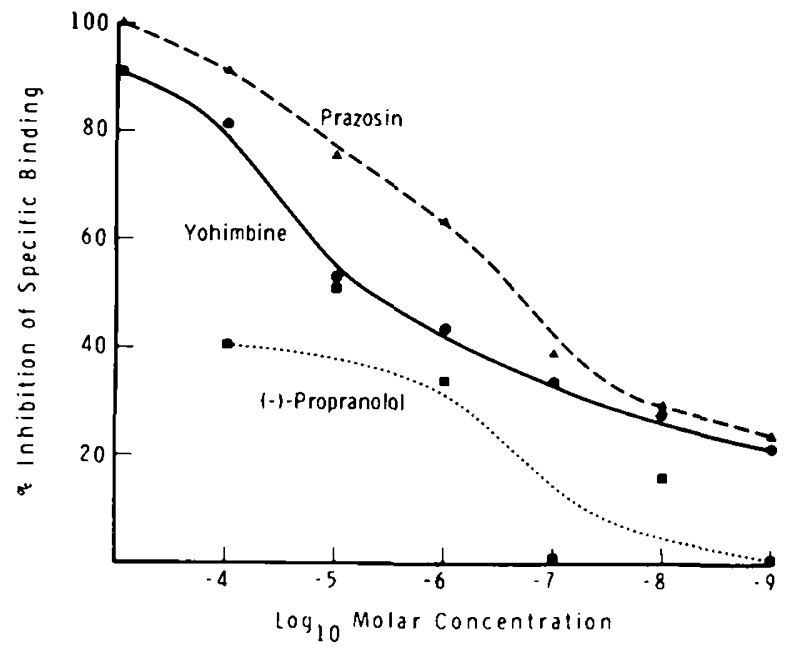

Fig. 2. The effect of varying concentrations of cold adrenergic antagonists on the \% inhibition of specific binding of $\left[{ }^{3} \mathrm{H}\right]-$ WB4 101 . Each point represents the mean of at least four experiments performed in triplicate. The concentration of $\left[{ }^{3} \mathrm{H}\right]-\mathrm{WB} 4101$ used in these experiments ranged from 4-7 nM.
Table 1. Alpha adrenoceptors in canine cardiac membranes from puppies and adult dogs

\begin{tabular}{cccc}
\hline Age & $\mathbf{N}^{1}$ & $\begin{array}{c}\text { Maximum re- } \\
\text { Dissociation con- } \\
\text { stant } \mathbf{K}_{\mathrm{d}}\left(\mathbf{\times} 10^{-9} \mathrm{M}\right)\end{array}$ & $\begin{array}{c}\text { ceptor number } \\
\mathbf{R}_{\mathrm{o}} \text { f mole/mg } \\
\text { protein }\end{array}$ \\
\hline $1 \mathbf{w k}^{2}$ & 5 & $2.33 \pm 0.768$ & $233 \pm 63$ \\
$3-5 \mathbf{w k}^{2}$ & 3 & $2.17 \pm 0.230$ & $139 \pm 44$ \\
Adult & 4 & $\mathrm{NSB}^{3}$ & $\mathrm{NSB}$ \\
\hline
\end{tabular}

${ }^{1} \mathrm{~N}$, number of assays performed per age group.

${ }^{2}$ Each assay specimen was obtained from 3-4 puppies.

${ }^{3} \mathrm{NSB}$, no consistent specific binding.

puppies the $R_{\text {. was }} 139 \pm 44$. There was no difference between the $R$. values between one and 3-5-wk-old puppies.

\section{DISCUSSION}

In the present experiments in dogs, alpha adrenoceptors were demonstrated in puppy myocardium but were not demonstrable in adult dog heart. These studies agree with the report of Wei and Sulakhe (35), which also failed to demonstrate the existence of alpha adrenoceptors in the adult dog, and are comparable to the studies of Cheng et al. (9), which found alpha adrenoceptors in the fetal sheep heart but not in the heart of the ewe.

The physiologic role of alpha adrenoceptors in the heart was not examined in the present experiments. Although it has been reported that alpha adrenoceptors increase myocardial contractility in the adult $(3,13,15-17,23,30)$, negative inotropic effects have also been noted $(29,34)$. Wenzel and Su $(36)$ have postulated that there are alpha and beta stimulatory and alpha inhibitory receptors in the heart. The negative inotropic effect of alpha inhibitory receptors have been shown only under conditions of high cellular calcium and during rapid stimulation [conditions that may be present in the neonatal environment (27)]. If indeed alpha adrenoceptors can produce a negative inotropic response, the high receptor density for alpha adrenoceptors in the young reported here and the lower number of myocardial beta adrenergic receptors found in the newborn dog (24) could explain in part the decreased inotropic responses of the heart to both endogenous and exogenous catecholamines $(5-8,12,14,25)$.

As previously reported, the number of cardiac beta adrenoceptors is relatively low in the 1 -wk-old canine and increases with age. The combined studies therefore indicate a shift in receptor density with age. It has been suggested that alpha and beta adrenoceptors may be interconvertible isomeric forms of the same cell surface protein (20). It has also been proposed that beta receptors may regulate alpha receptor density (11). Our present findings taken together with our previous observation would support a close relationship between alpha and beta adrenoceptors.

\section{REFERENCES AND NOTES}

1. Alexander, R. W., Williams, T. L., and Lefkowitz, R. J.: Identification of cardiac beta adrenergic receptors by $(-){ }^{3} \mathrm{H}$ alprenolol binding. Proc. Nat. Acad. Sci., USA, 72: 1564 (1975).

2. Benfy, B. F.: Characterization of alpha-adrenoceptors in the myocardium. Br. J. Pharmacol., 48: 132 (1973).

3. Benfy, B. F. and Varma, D. R.: Interactions of sympathomimetic drugs, propranolol and phentolamine on atrial refractory period and contractility. Br. J. Pharmacol., 30: 603 (1967).

4. Bers, D. M.: Isolation and characterization of cardiac sarcolemma. Biochem. Biophys. Acta., 555: 131 (1979).

5. Boatman, D. L. and Brody, M. J.: Cardiac responses to adrenergic stimulation in the newborn dog. Arch. Int. Pharmacodyn., 190: 1 (1967).

6. Boatman, D. L., Shaffer, R. A., Dixon, R. L., and Brody, M. J.: Function of vascular smooth muscle and its sympathetic innervation in the newborn dog. J. Clin. Invest., 44; 421 (1965).

7. Buckley, N. M., Gootman, P. M., Gootman, N., Roddy, G. D., Weaver, L. D. and Crane, L. A.: Age dependent cardiovascular effects of afferent stimulation in neonatal pigs. Biol. Neonate, 30: 268 (1976).

8. Buckley, N. M., Gootman, P. M., Yellin, E. L., and Brazeau, P.: Age related cardiovascular effects of catecholamines in anesthetized piglets. Circ. Res., 45: 282 (1979)

9. Cheng, J. B., Cornett, L. E., Goldfein, A., and Robert, J. M.: Alpha adrenergic 
receptor is present in fetal but not adult sheep myocardium. Abstract \#693, Fed. Proc., 39: 3 (1980)

10. Cole, B., Brocklebank, J., Murray, B., Peterson, L., and Robson, A. M.: Maturation of the developing rabbit kidney: variations in cellular size and contents (in press, Pediatr. Res.)

11. Cryer, S. P.: Physiology and pathophysiology of the human neuroendocrine system. N. Engl. J. Med., 303: 436 (1980).

12. Driscoll, D. J., Gillette, P. G., Ezrailson, E. G., and Schwartz, A.: Inotropic response of the neonatal canine myocardium to dopamine. Pediatr. Res., 12: 42 (1978).

13. Fujimoto, L., Borda, L., Scuchleib, R., Corr, P., and Henry, P.: Alpha-adrenergic mediated enhancement of ventricular inotropy (Abst.) Circulation, 53-54: II192 (1976).

14. Geis, W. P., Tatooles, C. J., Priola, D. V., and Friedman, N. F.: Factors influencing neurohumoral control of the heart in the newborn dog. Am. J. Physiol., 228: 1685 (1975)

15. Giohi, A., Ledda, F., and Mannaioni, P. F.: Electrophysiological effects of alpha and beta receptor agonists and antagonists on Purkinje fibers of sheep heart. Br. J. Pharmacol., 32: 695 (1968).

16. Govier, W. C.: A positive inotropic effect of phenylephrine mediated through alpha-adrenergic receptors. Life Sci., 6: 1361 (1967).

17. Govier, W. C.: Myocardial alpha adrenergic receptors and their role in the production of a positive inotropic effect by sympathomimetic agents. J. Pharmacol. Exp. Ther., 159: 82 (1968)

18. Greenberg, D. A., U'Prichard, D. C., and Snyder, S. H.: Alpha noradrenergic receptor binding in mammalian brain. Differential labelling of agonist and antagonist states. Life Sci., 19: 69 (1976).

19. Karliner, J. S., Barnes, P. Hamilton, C. A., and Dollery, C. T.: Alpha one adrenergic receptors in guinea pig myocardium. Identification by binding of a new radioligand [ $\left.{ }^{3} \mathrm{H}\right]$-Prazosin. Biochem. Biophys. Res. Comm., 90: 1, 142 (1979).

20. Kunos, G. and Szentivanyi, M.: Evidence favoring the existence of single adrenoceptor. Nature, 217: 1077 (1968)

21. Lefkowitz, R. J.: Methods in hormone receptors. Ed. Blecher, M. pp. 53-72. (M. Dekker, N.Y.) (1975)

22. Lowry, O. H., Rosenbrough, N. J., Farr, A. L., and Randall, P. J.: Protein measurement with folin phenol reagent. 5. Biol. Chem., 193: 265 (1951).

23. Osnes, J. B.: Positive inotropic effect without cyclic AMP elevation after alphaadrenergic stimulation of perfused hearts from hypothyroid rats. Acta. Pharmacol. Toxicol., 38: 232 (1976)

24. Montgomery, S. B., Eisner, G. M., Hepner, S., Calcagno, P. L., and Jose, P. A.: Ontogeny of myocardial adrenergic receptors I. Beta-adrenoceptors (Submitted for publication).

25. Privitera, P. S., Loggie, J. M. H., and Gaffney, T. E.: A comparison of the cardiovascular effects of biogenic amines and their precursors in newborn and adult dogs. J. Pharmacol. Exp. Ther., 166: 293 (1969).

Copyright (c) 1982 International Pediatric Research Foundation, Inc. $0031-3998 / 82 / 1605-0340 \$ 02.00 / 0$
26. Raisman, R., Bailey, M., and Langer, S. Z.: Specific labelling of postsynaptic alpha one adrenoceptors in rat heart ventricle by $\left[{ }^{3} \mathrm{H}\right]-W B 1401$. Naunyn Schmiedeberg's Arch. Pharmacol., 307: 223 (1979).

27. Rosen, M. R., Rider, R. F., Hardof,, A. J., Davies, M., and Danilo, P. Jr.: Age related changes in purkinge fiber action potential of adult dogs. Circ. Res., 43: 931 (1978).

28. Scatchard, G.: The attractions of proteins for small molecules and ions. N.Y. Acad. Sci., 51: 660 (1949).

29. Schumann, H. J., Endoh, M., and Brodde, O. E.: Time course of the effects of beta and alpha-adrenoceptor stimulation by isoprenaline and methoxamine on the contractile force and CAMP level of the isolated rabbit papillary muscle. Naunyn Schmiedeberg's Arch. Pharmacol., 289: 291 (1975).

30. Schumann, H. J., Endoh, M., and Wagner, J.: Positive inotropic effects of phenylephrine in isolated rabbit papillary muscle medicated both by alpha and beta-adrenoceptors. Naunyn Schmiedeberg's Arch. Pharmacol., 284: 133 (1974).

31. Solomon, Y., Landas, C., and Rodbell, M.: A highly sensitive adenylate cyclase assay. Anal. Biochem., 58: 541 (1974).

32. U'Pritchard, D. C., Charness, M. E., Robertson, D., Snyder, S. H.: Prazosin: differential affinities for 2 populations of alpha-noradrenegic receptor binding sites. Eur. J. Pharmacol., 19: 69 (1976).

33. Wagner, J., Brodde, O. E.: On the presence and distribution of alpha adrenoceptors in the heart of various mammalian species. Naunyn-Schmiedeberg's Arch. Pharmacol., 302: 239 (1978).

34. Watanabe, A. M., Hathaway, D. R., Besech, R., Farmer, B. B., and Harris, R. A.: Alpha-adrenergic reduction of cyclic adenosine monophosphate concentrations in rat myocardium. Circ. Res., 40: 596 (1977).

35. Wei, J. W and Sulakhe, P. V.: Regional and subcellular distribution of beta and alpha adrenergic receptors in the myocardium of different species. Gen. Pharm., 10: 263 (1979).

36. Wenzel, D. G. and $\mathrm{Su}, \mathrm{J}$. T.: Interaction between sympathomimetric amines and blocking agents on the rat ventricle strip. Arch. Int. Pharmacodyn., 160: 379 (1966).

37. Williams, R. S., and Lefkowitz, R. J.: Alpha adrenergic receptors in rat myocardium. Circulation Research, 43: 721 (1978)

38. Yamada, S., Vamamura, H. T., and Roesne, W. R.: Characterization of cardiac alpha adrenergic receptors by ${ }^{3} \mathrm{H}$-WB4101 and alteration following chemical sympathectomy. Abstract \# 700, Fed. Proc., 39: 3 (1980).

39. The authors thank Mrs. Carolyn Patterson for secretarial assistance.

40. This research was supported by a grant from the National Heart, Lung and Blood Institute HL23081-03.

41. Requests for reprints should be addressed to: Dr. Robin Felder, Department of Pediatrics, Georgetown University Hospital, 3800 Reservoir Road, N.W., Washington, D.C. 20007

42. Received for publication May 8,1981

43. Accepted for publication October $27,1981$. 